\title{
Exploring Factors That Lead to Students Dropout in Public Secondary Schools in Al'Ain
}

\author{
Fatima Khamis Abdulla Alkaabi
}

Faculty of Management \& Economics, University of Pendidikan Sultan Idris, Tanjung Malim. Malaysia

Mohd Asri Bin Mohd Noor

Associate Professor Dr., Faculty of Management \& Economics, University of Pendidikan Sultan Idris, Tanjung Malim. Malaysia

\begin{abstract}
For any educational institution, students are most important. Universities and colleges have no value without students. The educational process is an integrated process involving the family, the school and the entire community to reach effective outputs. There are a number of factors that negatively affect at-risk students' retention in school and graduate such as socioeconomic status. Phenomenon of dropout where thousands of students dropped out is prevalent and constant in urban schools across the United States (Brown, 2015). This research is important for academic reason; it gives academic practitioners vital information that can be utilized to develop the education. The information was collected by interviews questions with students. The information collected were analyzed by using coding and theme with Nvivo program. The research showed that the factors affect in Retention of secondary stage's students in Al Ain.
\end{abstract}

Keywords: Drop-out, phenomenon, factors, Student Retention, Socioeconomic status.

\section{Introduction}

The phenomenon of dropout is one of the main problems that hinder the educational process in particular in the developing countries (Eissa, 2016). The phenomenon of students dropping out of high school has also gained renewed attention, with researchers, educators and policy makers wanting to know how many students are dropping out, what causes dropout, and what may be done to prevent it (Heckman \&Paul,2007; Orfield,2004).

Dropout is an alarming issue, which affects the socio-economic development. Pupils' dropout does not only affect the community they belong to but also affects the nation at large. Pupils dropping out from schools leads to wasteful utilization of scarce educational resources without achieving the nation's educational aspirations. This does not mean well for healthy educational system and would have negative effect on the economy of the state because those who dropped out may create higher future costs (Segumba, 2015). Students dropout has both a negative personal effect and an economic impact on the individual and the community (Brown, 2015).

Economic and social development of a country depends on education (Ali, Jusof, Ali, Mokhta, \& Salamat, 2009). Most of the previous studies on student's performance focused on issues like teacher education, class environment, gender difference, teaching style, family educational background and socioeconomic factor (Singh, Malik, \& Singh, 2016).

\section{Problem Statement}

In UAE, the high rates of absenteeism among students before and after public holidays and classroom exams are a problem that affects the educational field and the school administration and casts a negative shadow on the educational process. It also affects the annual plan of the lesson. School principals and parents confirmed that the high absentee rates among students after the holidays have become a phenomenon experienced by the departments of schools and teaching bodies and cast a negative shadow on the field of education, demanding the need to include some field activities in the curriculum that will reduce boredom and breathe the spirit of vitality among students. These will make the school environment more attractive to them. In addition, parents are also asked to bring their children to school so as not to miss the grades of assessment in the written and oral examinations. (Eisam, 2014). 
Educators warned against the decline in the demand of students in public and private schools for education in recent years and missing of motivation between students in the UAE, they explained that "most of the students are indifferent to studying, do not focus on explaining the teachers, and spend the school day between sleeping and playing", calling on the Ministry of Education to restructure its educational plans, policies and programs, to motivate students to learn, they attributed the problem to the lack of attractiveness of the curriculum contents, the absence of incentives from the teaching profession, the application of the three classroom system, the weak control of parents over their student children, and the weak communication between home and school, so the policies to improve students retention are very important. The students in the twelfth grade, emphasized that most students do not care to explain the teachers, or to study their lessons, and spend their school day between sleeping and playing, they added that this is due to their boredom from the existing teaching methods, from the many examinations, as well as the availability of other methods of learning outside the school, which keeps them from attending school, noting private lessons and academic summaries. (Alsoba'ei, 2011). However, the gap is no previous researches have been done on exploring factors which lead students to dropout in UAE.

\section{Literature review}

While there is no reasonable and predictable definition, theoretical frameworks are characterized as any observational or semi experimental theory of social as well as psychological procedures, at various levels, that can be connected to the understanding of phenomena (Anafara \& Mertz, 2006; Fountain, 2014). Retention theories provide the theoretical orientation for the context of this study. The researcher investigated different theories of diligence and retention, in that discovering ideas which related to each theory.

To spotlight on factors or obstacles of dropout there were many theories that were studied included George Kuh's theory of student engagement. In addition, the researcher reviewed motivation theories such as Maslow's hierarchy of needs, Glasser's choice theory, the expectancy-value theory by Vroom and Need to achieve theory. So as to discover more profundity and to find more depth intrinsic and extrinsic motivation will also review. According to Bozack (2011), motivation research incredibly adds to the comprehension of ideas identified with student accomplishment. Also, the researcher in current research will review environmental and social affects through the social cognitive theory and the adaption with the different stress through attribution theory.

All the educational conferences in the UAE (which resulting and transferring the decisions of ministry of education) focus on developing the quality of education and finding solutions to general factors to attract students to the educational process, for example, Al Shihi ( member in the UAE Federal National Council (FNC) said in an educational conference that the statistics of students dropout, repeating a grade and achieving low examination results in public schools have become a cause of concern and called for the issue to be addressed (Al Serkal, 2018). But what are the factors which lead students to dropout, this investigation will spotlight on that point. Attaway and Bry, (2004); Nelson and Guerra, (2014) mentioned some of the specific factors that encourage students to education and their academic achievement (a) environmental such as family income; (b) parents level of education; (c) occupational status; (d) neighborhood environments; (e) school factors to include teacher expectations; and (f) school environment.

\section{Research Methodology}

The purpose of this qualitative research is to understand the factors and influences that reduced retention of male and female students in the secondary stage of Al Ain schools as well as experiences that the students perceived as helpful to their persistence along the academic journey.

This research is based on the information that can be obtained from different students, teachers and parents.

\subsection{Instruments}

The instrument in the qualitative research is the researcher. the researcher will use observation, interviews and documents data with students in Al Ain city who already drop out during the last 1-2 years, each participant will be informed in advance that the interview session will take about half an hour at the location determined by the participant himself. Also they will be informed by the numbers of questions, so the researcher will tell them there will be eleven questions through interview, the strategy of interview will be fact-to-face by asking questions, recording the answers to get every things from participations, taking notes and watching reactions to register the notes, during that the researcher will take permission from participations regarding any questions, also the researcher will not initiate any other communication with the 
participations outside the meeting procedure that relate to subject, also the researcher will not force any participant to complete this study. The name of participants will not be mentioned in the research.

\section{Data Analysis \& Result}

In this study, the researcher uses comprehending, synthesizing, theorizing and re-contextualizing method to explore the factors that lead to student's dropout within different types of theories. The findings of the present study assist the educational officials in the formulation of effective retention policies. For instance, the exploring is deep way to know what that factors lead to dropout.

\begin{tabular}{|c|c|c|c|}
\hline Research Objectives & Research Questions & Theories & Data Analysis \\
\hline $\begin{array}{l}\text { 1.To explore the perceived } \\
\text { factors that contribute to } \\
\text { students dropping out of school } \\
\text { in secondary stage. }\end{array}$ & $\begin{array}{l}\text { 1. What perceived factors } \\
\text { contribute to students dropping } \\
\text { out from school in secondary } \\
\text { stage? }\end{array}$ & $\begin{array}{l}{ }^{*} \text { Retention theory } \\
{ }^{*} \text { Choice theory }{ }^{*} \text { Social } \\
\text { Cognitive theory/ }\end{array}$ & $\begin{array}{l}\text { comprehending, } \\
\text { synthesizing, theorizing } \\
\text { re-contextualizing }\end{array}$ \\
\hline $\begin{array}{l}\text { 2. To explore the importance of } \\
\text { the family's socioeconomic } \\
\text { status on student's persistence } \\
\text { in schools setting. }\end{array}$ & $\begin{array}{l}\text { 2. What is the importance of the } \\
\text { family's socioeconomic status } \\
\text { on student's persistence in } \\
\text { schools setting? }\end{array}$ & *Need to achieve theoryl & $\begin{array}{l}\text { comprehending, } \\
\text { synthesizing, theorizing } \\
\text { re-contextualizing }\end{array}$ \\
\hline $\begin{array}{l}\text { 3. To identify what perceived } \\
\text { coping mechanisms students } \\
\text { think they need to implement as } \\
\text { they encounter stressors to } \\
\text { adapt with the factors that lead } \\
\text { them to dropout. }\end{array}$ & $\begin{array}{l}\text { 3. What coping mechanisms do } \\
\text { intermediate and secondary } \\
\text { students think they need to } \\
\text { implement as they encounter } \\
\text { stressors to adapt with the } \\
\text { factors that lead them to } \\
\text { dropout? }\end{array}$ & ${ }^{\star}$ Attribution theory & $\begin{array}{l}\text { comprehending, } \\
\text { synthesizing, theorizing } \\
\text { re-contextualizing }\end{array}$ \\
\hline $\begin{array}{l}\text { 4. To explore the students } \\
\text { perceived motivations to } \\
\text { continue their study or drop out. }\end{array}$ & $\begin{array}{l}\text { 4. What are the students } \\
\text { perceived motivations to } \\
\text { continue or drop out? }\end{array}$ & $\begin{array}{l}{ }^{\star} \text { Intrinsic \& } \\
\text { Extrinsic motivation theory } \\
{ }^{\star} \text { Social Cognitive Theory } \\
\wedge \text { ^Hierarchy of needs theory/ }\end{array}$ & $\begin{array}{l}\text { comprehending, } \\
\text { synthesizing, theorizing } \\
\text { re-contextualizing }\end{array}$ \\
\hline $\begin{array}{l}\text { 5. To explore policies that } \\
\text { students perceived can be } \\
\text { implemented to improve their } \\
\text { retention in schools. }\end{array}$ & $\begin{array}{l}\text { 5. What policies students } \\
\text { perceived that can be } \\
\text { implemented to improve their } \\
\text { retention in the schools? }\end{array}$ & $\begin{array}{l}{ }^{*} \text { Retention theory } \\
\text { *Social Cognitive Theory } \\
\text { ^Hierarchy of needs theory/ }\end{array}$ & $\begin{array}{l}\text { comprehending, } \\
\text { synthesizing, theorizing } \\
\text { re-contextualizing }\end{array}$ \\
\hline
\end{tabular}

\section{References}

[1] Ali, N., Jusof, K., Ali, S., Mokhtar, N., \& Salamat, A.S.A. (2009). The Factors Influencing

[2] Students' Performance at Universiti Teknologi Mara Kedah, Malaysia. Management Science and Engineering, 3(4), P 81-90

[3] Al Serkal, Mariam, M. (2018). UAE Minister to be questioned over students' low scores. Gulf News.

[4] Alsoba'ei, W. (2011). Educators: Students 'motivation to education is declining. Emaratalyom. Dubai.

[5] Anafara, Jr., V. A. \& Mertz, N. (2006). Theoretical frameworks in qualitative research. Thousand Oaks, CA: Sage Publications, Inc.

[6] Attaway, N. M., \& Bry, B. H. (2004). Parenting style and black adolescents' academic achievement. Journal of Black Psychology, 30(2), 229-245. doi:10.1177/0095798403260720

[7] Bozack, A. (2011). Reading between the lines: Motives, beliefs, and achievement in adolescent boys. The High School Journal, (94)2, 58-76.

[8] Brown, K.E. (2015). The Link Between Leadership and Reduced Dropout Rates. Walden University.

[9] Eisam aldin. (2014). Official leave holidays shake schools. Albayan. UAE.

[10] Eissa, R. (2016). Child labor and its relation to school dropout A field study of a sample of abandoned working children - Biskra. University of Mohammed Khader Biskra. 
[11] Fountain, S. (2014). Stopping out: Experiences of African American females at a Midwestern community college. Retrieved from: http://lib.dr.iastate.edu/etd/14161

[12] Heckman, J. J. \& Paul, L. (2007). "The American High School Graduation Rate: Trends and Levels." NBER (Working paper W13670). Available online: http://ssrn.com/ abstract=1073650

[13] Nelson, S. W., \& Guerra, P. L. (2014). Educator beliefs and cultural knowledge: implications for school improvement efforts. Educational Administration Quarterly, 50(1) 67-95. doi: 10.1177/0013161X13488595

[14] Orfield, G. (2004). Dropouts in America: Confronting the Graduation Rate Crisis. Cambridge, MA: Harvard Education Publishing Group.

[15] Segumba, S, I. (2015). Factors Leading to Problems of Drop Out in Primary School Pupils in Temeke District. University of Tanzania.

[16] Singh, S.P., Malik,S \& Singh,P.(2016). Factors Affecting Academic Performance of Students. Volume5. Issue:4 